\title{
The Effects of Odd or Even Number of Options on The Variance of Item Validity in Environmental Personality (Big-Five Personality)
}

\author{
Rahmirini Datau', I Made Putrawan², Wardani Rahayu ${ }^{3}$ \\ $1,2,3$ State University of Jakarta, Indonesia \\ Email: rahmirinidatau0@gmail.com
}

\begin{abstract}
Validity is one of the important characteristics in any psychological measuring tool. Measurement tools in his research more generally include a variety of observations and usually include responses that aim to regulate and limit the choices available to respondents and assessments. There are many studies that have assessed how the number of response options on a scale affects validity and reliability, but fewer have discussed whether the midpoint should be included as a response option, or whether the scale is even. Regardless of where the response scale is in psychological measurements, the environmental personality (big-five personality) scale has been expanded and elaborated in various ways in previous research since the introduction of dreams. The bigfive personality model is the most extensive model for measuring environmental personality. This study aims to determine whether there is a difference between the number of odd and even option scales on the validity variance of students' environmental personality (big-five personality) items, and to see which scale of the number of options is better or suitable for the environmental personality (big-five personality) instrument. The calculation data were analyzed using the one-way ANOVA method. The results of this study indicate that the scale of the number of odd options (five options) and the scale of the number of even options differ significantly in the variance of the validity of the environmental personality items (big-five Personality). The mean plot results show that the odd option scale higher than the even scale. This research can be carried out for further research in using the odd scale on the environmental personality measurement tool (Bigfive Personality) with the expansion being studied.
\end{abstract}

Keywords: Item Validity Variance, Environmental Personality (Big-Five Personality), Number of Even Options, Number of Odd Options.

\section{A. INTRODUCTION}

Validity is a very important attribute attached to a test because of the entire process of measuring psychological attributes, the peak is in the issue of validity (Azwar, 2016). Validity is one of the important characteristics (property) in any psychological measuring tool (Ary at al., 1985; Baltes at al., 1988; Elmes at al., 1992; Fridenberg, 1995). To produce good items, namely the contribution of each item to the measurement error, the test score should be kept to a minimum. This correlation coefficient is also known as the item-total correlation coefficient, iA or riA. Item validity is used in item analysis in the context of measuring to improve the measuring instrument, it is hoped that a good and reliable measuring instrument will be obtained (Naga, 2004).

Measurement tools in research more generally include a wide variety of observations and methods usually include response scales that aim to regulate and limit the choices available to respondents and facilitate assessment. Psychological 
tests usually include a response scale that aims to regulate and limit the choices available to respondents and facilitate assessment. One such response scale is the Personality scale, which was originally introduced to have a specific 5-point form. In practice, such scales vary widely in the nature and number of response options. However, relatively little consensus exists regarding some of the questions that have emerged regarding the use of personality scales namely, is there a "psychometrically optimal" number of response options? Is it better to include an even or an odd number of answer options? There are many studies that have assessed how the number of response options on a scale affects validity and reliability (Bishop, 1987; Cox, 1980; Lissitz \& Green, 1975; Oaster, 1989). However, fewer studies have addressed whether the midpoint should be included as a response option (Kalton, Roberts, \& Holt 1980; Weems \& Onwuegbuzie, 1980). However, regardless of the place where the response scale occupies in psychological measures, the environmental personality (big-five personality) scale has been expanded and elaborated in various ways in previous research since its original introduction. Measurement data generally guide the scale of choices researchers make regarding response scales (Smith, 2005). The big-five personality model is the most extensive model for measuring environmental personality. (Friday, 2004). (Markowitz et al., 2012). Human activity can not be separated from human personality, broadly about personality which is categorized as big-five personality, namely neuroticism, extraversion, openness, agreeableness and conscientiousness (Colquitt, 2005).

At present, the optimal number of choice options used in the item is a topic that is still debated, due to the lack of strong conclusions from empirical and theoretical findings. One of the debates is between using an even or odd number of options-scale, to minimize the effect of guesswork which results in a lower number of options (Suchindran, 2014). Several lines of thought can influence one's view of the optimal number of points on the number of options on the environmental personality scale. First, given the importance of score variance in classical test theory, a response scale that results in an increase in the variance of valid scores should increase the precision of the measurement thereby, maximizing the coefficients of validity and reliability. (Simms et al., 2019a).

Accurate measurement is not only a function of the wording of the items but also the effect of the response options attached to the items (Nadler et al., 2015). One of the most important parameter of the item measurement function is the statistic that shows the suitability between the item function and the overall instrument function. Hirsh, (2014). Based on this study, the researchers conducted a study namely "The Effect of the Number of Even and Odd Response Options on the Variance of Environmental Personality Item Validity (Big-Five Personality)".

\section{B. METHOD}

This study aims to obtain information on the difference in the scale of the number of even and odd options on the variance of the validity of the items on the environmental personality (big-five personality) measuring instrument of students as 
well as to find the causes that allow the high and low validity of the items (item validity) on the difference in the scale of the number of even and odd options. . Therefore, this study used one-way ANOVA analysis. This research was conducted at State Senior High School 16 Jakarta. The time of the study was carried out in the Odd Semester of 2021/2022 with the number of samples per cell, namely 100 students.

In this study the population is all students of State Senior High School in Jakarta Province. Determination of the sample in this study using a multi-stage sampling technique with the following stages: first, using a purposive sampling technique from all public high schools in Jakarta and selected public high schools in West Jakarta. Second, by using a cluster random sampling technique from all subdistricts in the Jakarta area, Palmerah sub-district was selected. Third, by using a cluster random sampling technique from all public high schools in Palmerah subdistrict, State Senior High School 16 Jakarta was chosen as the research site. Fourth, using simple random sampling to determine respondents.

\section{RESULTS AND DISCUSSION}

Based on the research that has been done, the data that will be displayed are descriptive statistics consisting of Mean, Std. Deviation, Minimum, Maximum and Sum of the variance of the validity of the Environmental Big Five Personality of students. The following is a description of each group.

Table 1. Summary of Research Descriptive Statistics

\begin{tabular}{ccc}
\hline Description & Option Number Scale 5 & Option Number Scale 4 \\
\hline Mean & 0.287 & 0.174 \\
Std. Deviation & 0.145 & 0.085 \\
Minimum & 0.030 & 0.020 \\
Maximum & 0.510 & 0.320 \\
Sum & 8.657 & 5.229 \\
\hline
\end{tabular}

The data that has been obtained through the distribution of the environmental big-five Personality instruments of students in this study, then the validity variance of the environmental big-five Personality of each group was tested for normality and homogeneity as a prerequisite test for analysis.

The calculation of the normality test of the student's environmental big-five Personality validity variance was carried out using the Kolmogorov-Smirnov test with a significance level of $=0.05$. From the two groups of data normally distributed, ie accept $\mathrm{H} 0$ if $\mathrm{KS}>0.05$ because it falls in the accepted area.

Table 2. Normality Test Results.

Tests of Normality

\begin{tabular}{llcccccc}
\hline \multirow{2}{*}{$\begin{array}{l}\text { Item validity } \\
\text { Number of options-scale }\end{array}$} & \multicolumn{3}{c}{ Kolmogorov-Smirnov } & \multicolumn{3}{c}{ Shapiro-Wilk } \\
\cline { 2 - 8 } variance & & Statistic & $\mathrm{df}$ & Sig. & Statistic & $\mathrm{df}$ & Sig. \\
\cline { 2 - 8 } & 5 option number scale & .115 & 30 & $.200^{*}$ & .947 & 30 & .140 \\
& option number scale 4 & .099 & 30 & $.200^{*}$ & .965 & 30 & .404 \\
\hline
\end{tabular}

${ }^{*}$ This is a lower bound of the true significance.

a. Lilliefors Significance Correction 
Data homogeneity test Variance of the validity of the environmental big-five Personality of students using Levene's test from table 2. Based on the Levene statistic test, the results of Sig. $>0.05$ i.e. $0.587>0.05$ at $=0.05$ then accept Ho, meaning that the variance of the environmental validity of the big-five Personality of students has the same variance or is homogeneous.

Table 3. Homogeneity Test Results

Test of Homogeneity of Variances

\begin{tabular}{cccc}
\hline Item validity variance & & & \\
\hline Levene Statistic & df1 & df2 & Sig. \\
.299 & 1 & 58 & .587 \\
\hline
\end{tabular}

Because the data has a normal and homogeneous distribution, an analysis test was carried out, namely with one-way ANOVA, the results of the analysis can be seen in table 4.

Table 4 One-way ANOVA Test Results

ANOVA

\begin{tabular}{lccccc}
\hline Item Validity Variance & \multicolumn{1}{l}{} & & & \\
\hline & Sum of Squares & $\mathrm{df}$ & Mean Square & $\mathrm{F}$ & Sig. \\
\hline Between Groups & .176 & 1 & .176 & 12.392 & .001 \\
Within Groups & .824 & 58 & .014 & & \\
\hline Total & 1.000 & 59 & & & \\
\hline
\end{tabular}

Based on the ANOVA output above, it is known that the sig value is $0.001<$ 0.05 and at the $5 \%$ level by comparing between $\mathrm{F}_{\text {count }}$ and $\mathrm{F}_{\text {table, }}$ it is found that $\mathrm{F}_{\text {count }}=$ $12,392>F_{\text {table }}=4,007 \mathrm{H} 0$ is rejected, so it can be concluded that from the scale of the number of odd options (five options) and the number of even options (four options) differed significantly in the variance of the validity of the environmental personality items (big-five Personality). This research is supported by the results of a previous study conducted (Leonard J, et al) in 2019 entitled "Does the Number of Response Options Matter? Psychometric Perspectives Using Personality Questionnaire Data" the result of his research is that a number of response options have an impact on the accuracy of the scale measurement, which has important implications for how psychological measures should be developed and used in practice. To see which number of options is better/matched between the odd option scale (five options) and the even option scale (four options) for measuring environmental personality (big-five Personality), the following is the result of the mean plot on a scale of four and five. 


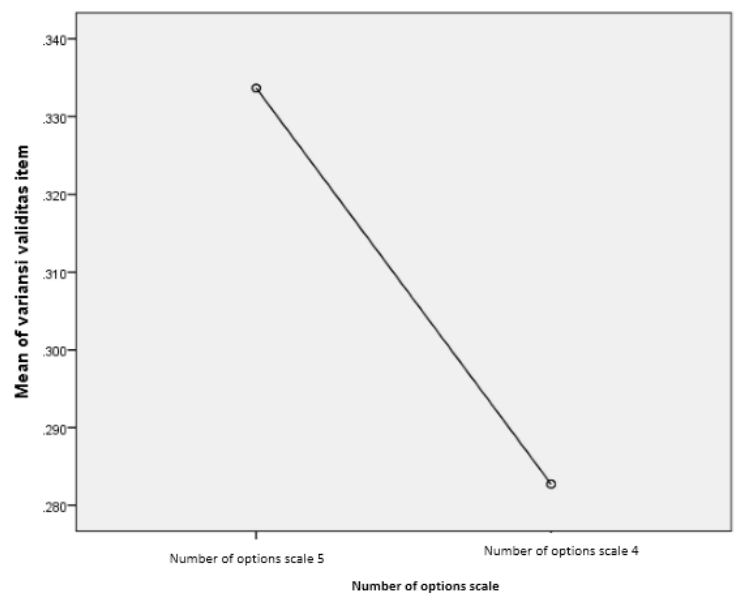

Figure 1. Mean Plot

The results of the mean plot above show that the odd option scale is higher than the even option scale on the variance of the validity of the environmental personality (big-five Personality) item. The results of research conducted (Kulas \& Stachowski, 2013) that the odd-numbered scale will show an advantage, psychometrically, over the even-numbered scale. This result is generally supported, because the correlation between alpha and criterion validity generally shows an advantage for odd scales relative to even scales. The optimal number of answer choices is a debate based on how simple a scale is while maintaining validity and reliability as interval data (Cox, 1980). So far, the five options are still the most commonly used, but more and more studies suggest the use of the three options because they have similar psychometric properties, are more efficient for development and management (Suchindran, 2014). A person's personality or personality in answering questions should not use the even option, because respondents who have evasiveness who always look for safety will not be accommodated, as for someone who has any acquiesced nature who is chosen strongly agrees, this will lead to biased data. Therefore, this research is a research that has the latest in measuring environmental big-five personality measuring instruments

\section{CONCLUSION}

The scale of the number of odd options (five options) and the scale of the number of even options (four options) differ significantly in the variance of the validity of the environmental personality items (big-five Personality). the odd option scale is higher than the even option scale on the variance in the validity of environmental personality items (big-five Personality). A person's personality or personality in answering questions should not use the even option, because respondents who have evasiveness who always look for safety will not be accommodated, as for someone who has any acquiesced nature that is chosen strongly agrees, this will lead to biased data. 


\section{REFERENCES}

1. Ary, D., Jacobs, L.C., \& Razavieh, A. (1985). Introduction to Research In Education (third ed). New York: Holt, Rinehart and Winston.

2. Azwar, S. (2016). Reliabilitas Dan Validitas Aitem. Buletin Psikologi, 3(1), 19-26. https://doi.org/10.22146/bpsi.13381

3. Baltees, P.B., Reese, H.W., \& Nesselroads, J.R. (1988). Introduction to research Methods in Life span Developmental Psychology. New Jersey: Lawrence Erlbaum Associates, Publishers

4. Bishop, G. F. (1987). Experiments with the middle response alternative in survey questions. Public Opinion Quarterly, 51, 220-232.

5. Colquitt, J. A., Lepine, J. A., \& Wesson, M. J. (2005). Improving performance and outcomes. In Practice Development in Health Care (Vol. 4, Issue 4). https://doi.org/10.1002/pdh.22

6. Cox, E. (1980). The optimal number of response alternatives in a scale: A review. Journal of Marketing Research, 17, 407-422.

7. Elmes, D.G., Kantowitz, B.H., \& Roedriger III, H.L. (1992). Research methods in Psychology. New York: West publishing Company.

8. Friday, A. S. (2004). Criterion-Related Validity of Big Five Adolescent Personality Traits. In Doctoral Dissertations University.

9. Friedenberg, L. (1995). Psychological Testing. Design, Analysis, and Use. Boston: Allyn and Bacon.

10. Hirsh, J. B. (2014). Environmental sustainability and national personality. Journal of Environmental Psychology, 38, 233-240.

11. Kalton, G., Roberts, J., \& Holt, D. (1980). The effects of offering a middle response option with opinion questions. Statistician, 29, 65-78.

12. Kulas, J. T., \& Stachowski, A. A. (2013). Respondent rationale for neither agreeing nor disagreeing: Person and item contributors to middle category endorsement intent on Likert personality indicators. Journal of Research in Personality, 47(4), 254262. https://doi.org/10.1016/j.jrp.2013.01.014

13. Lissitz, R.W., \& Green, S. B. (1975). Effect of the number of scale points on reliability: A Monte Carlo approach. Journal of Applied Psychology, 60, 10-13.

14. Nadler, J. T., Weston, R., \& Voyles, E. C. (2015). Stuck in the middle: The use and interpretation of mid-points in items on questionnaires. Journal of General Psychology, 142(2), 71-89. https://doi.org/10.1080/00221309.2014.994590

15. Naga, D. S. (2004). Ketidaktepatan Penggunaan Validitas Butir dan Koefisien Reliabilitas dalam Penelitian Pendidikan dan Psikologi. Ilmu Pendidikan, II(2).

16. Oaster, T. R. F. (1989). Number of alternatives per choice point and stability of Likert- type scales. Perceptual and Motor Skills, 68, 549-550.

17. Simms, L. J., Zelazny, K., Williams, T. F., \& Bernstein, L. (2019). Does the Number of Response Options Matter? Psychometric Perspectives Using Personality Questionnaire Data. Psychological Assessment, 31(4), 557-566. https://doi.org/10.1037/pas0000648 
18. Smith, G. T. (2005). On the complexity of quantifying construct validity. Psychological Assessment, 17(4), 413-414. https://doi.org/10.1037/1040-3590.17.4.413 19. Suchindran, C. M. (2014). Sample Size Sample Size. Sampling and Choosing Cases in Qualitative Research: A Realist Approach, 3(X), 2014

20. Weems, G. H., \& Onwuegbuzie, A. J. (2001). The impact of midpoint responses and reverse coding on survey data. Measurement and Evaluation in Counseling and Development, 34, 166-176 